Bajopas Volume 2 Number 1 June, 2009

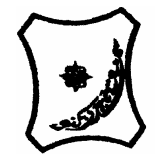

Bayero Journal of Pure and Applied Sciences, 2(1):101- 104

Received: April, 2009

Accepted: May, 2009

\title{
STUDY ON THE PHYTOCHEMICAL AND INVITRO ANTIBACTERIAL ACTIVITY OF SOME SPICE EXTRACTS ON SOME BACTERIA ISOLATED FROM MEAT PRODUCTS
}

\author{
${ }^{*}{ }^{1}$ Shamsuddeen, U. ${ }^{2}$ Ameh, J. B. ${ }^{1}$ Oyeyi T. I. and ${ }^{1}$ Dantata, A. A. \\ ${ }^{1}$ Department of Biological Sciences, Bayero University, Kano Nigeria. \\ ${ }^{2}$ Department of Microbiology, Ahmadu Bello University, Zaria Nigeria. \\ *Correspondence Author: msdeen1@yahoo.com
}

\begin{abstract}
The invitro activity of ethanolic and water extracts of some spices on some bacteria isolated from kilishi (a traditional meat snack) was investigated by disc diffusion method. Disc concentrations of 10, 100, 1000, 2000 and 3000 $\mathrm{gg}$ were used. The result showed that the ethanolic extract of ginger was active against Salmonella at disc concentrations of 100, 1000, 2000 and 3000 $\mu$, with zone diameters of 8, 19, 26 and $30 \mathrm{~mm}$ respectively. The ethanolic extract of cloves was active against Salmonella spp at disc concentrations of 10, 100, 1000, 2000 and 3000 $\mu$, with zone diameters of 13, 24, 25, 26 and 26mm respectively. The ethanolic extract of West African Black pepper was

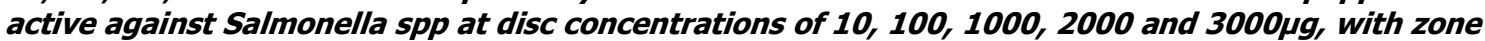
diameters of 12, 14, 20, 22 and $23 \mathrm{~mm}$ respectively. The ethanolic extract of pepper was active

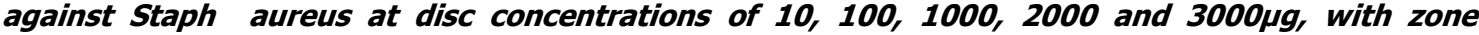
diameters of 11, 12, 16, 22 and 34mm respectively. The ethanolic extract of cloves was active

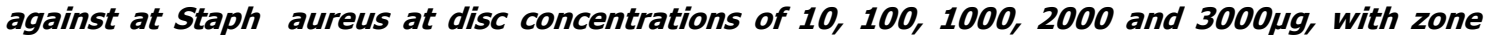
diameters of 12, 13, 13, 17 and $22 \mathrm{~mm}$ respectively. There was no activity on $E$. coli. The mixture of all the extracts however was not active on all the test organisms at the above mentioned disc concentrations. Each of the extracts contains at/east three of such secondary metabolites as alkaloids, tannins, flavonoids, saponins, reducing sugars and steroids. It could be recommended that bioactivity of spices should not be relied upon in the reduction of microbial populations of meat products. The ethanolic fractions of the spices should be put to further pharmacological in vivo tests to elucidate their potency, toxicity and efficacy.
\end{abstract}

Key words: Phytochemical, bioactivity, spices, bacterial isolates, kilishi.

\section{INTRODUCTION}

Production and consumption of traditionally prepared meat products is a common practice in many parts of the world (Vilar et al 2000). Kilishi is one of these products. It is a sun dried spiced and grilled meat snack that can be kept for considerably long time without getting spoiled due to its dry nature. During the production of the various traditional meat products, spices are applied at one point or the other.

Spices could be defined as the natural vegetable products or mixtures thereof, without any extraneous matter that is used for flavoring, seasoning and imparting aroma to foods (International Standard Organisation, 1972). These spices used in the production of Kilishi, are ginger, pepper, cloves and West African black pepper. These spice ingredients are reduced to powder and mixed in water, so that the dried meat is dipped into the liquid spice mixture, which also consists of groundnut, salt and seasoning.

Spice ingredients are thought to have some antimicrobial activities, and yet meat treated with spices have high microbial load (Shamsuddeen, 2009). There is there fore the need to investigate the antibacterial activities of extracts from the various spice ingredients, on bacteria isolated from the meat products.

\section{MATERIALS AND METHODS}

Isolation of the test organisms from meat snack (kilishi)

This was carried out according to Food and Agriculture Organization (1979). For E. coli, EMB plates were streaked with inoculum from from gas positive tube of lactose broth. Colonies that showed green metallic sheen were streaked on to agar slant and kept for biochemical characterization (indole and methyl red test). For Staphylococcus, Plates of mannitol salt agar were inoculated and incubated at $35^{\circ} \mathrm{C}$ for $24 \mathrm{hrs}$. Following incubation, mannitol fermenting organisms which showed a yellow zone surrounding their growth were isolated on to agar slants for biochemical tests (coagulase and catalase tests). For Salmonella spp a loopful of inoculum from the enrichment medium (selenite cystine medium) was streaked onto brilliant green agar plates and incubated at $37^{\circ} \mathrm{C}$ for $24 \mathrm{hrs}$. The colonies were gram-stained and tested for motility. The gramnegative motile rods were inoculated on to nutrient agar slant for subsequent biochemical test (Kligler's iron agar test). 


\section{Collection and Identification of the spices}

Up to $1000 \mathrm{~g}$ of the spices were bought from Kurmi market of Dala Local Government, Kano State, Nigeria. These are confirmed at the herbarium section of Department of Biological Sciences by herbarium curator. They were reduced to powder using pestle and mortar.

\section{Extraction of ethanolic and water fractions from the spices.}

Three hundred grams $(300 \mathrm{~g})$ of each spice ingredient powder was suspended in water, and in $99 \%$ ethanol $(500 \mathrm{ml})$ in separate flasks. The suspensions were kept at room temperature and left 14 days with regular shaking. The suspensions were then filtered, and the solvents were removed (both water and ethanol) by evaporation to dryness at room temperature (Fatope et., al. 1993). These gave the extract used in preparing the stock solutions for further analysis.

\section{PHYTOCHEMICAL SCREENING OF THE SPICE EXTRACTS \\ Test for alkaloids}

This was carried out according to the method described by Ciulci, (1994). To $1.0 \mathrm{ml}$ of each extract in two separate test tubes, 3 drops of Dragendoff's reagent was added. An orange red precipitate/turbidity with Dragendoff's reagent, would indicate the presence of alkaloids.

\section{Test for flavonoids}

This was carried out according to the method of Sofowora, (1993). A piece of magnesium ribbon was added to $4 \mathrm{mg} / \mathrm{ml}$ of each extract. This was followed by the addition of concentrated hydrochloric acid $(\mathrm{HCl})$, drop wise. Crimson to magenta colour indicated the presence of flavonoids.

\section{Test for saponins}

This was carried out according to the method of Brain and Turner (1975). Half gram $(0.5 \mathrm{~g})$ of each extract was placed in a test tube and then $0.5 \mathrm{ml}$ of distilled water was added. The tube was then shaken vigorously. A persistent froth that lasted for at least 15 mins indicated the presence of saponins.

\section{Test for reducing sugars}

This was carried out according to the method of Brain and Turner (1975). One milliliter $(1 \mathrm{ml})$ of stock solution of each extract was diluted with $2 \mathrm{ml}$ of distilled water, followed by the addition of Fehling's solution $(A+B)$ and the mixtures warmed. Brick red precipitate at the bottom of the test tubes indicated the presence of reducing sugars.

\section{Test for steroids}

This was carried out according to the method described by Ciulci (1994). Two grams (2g) of each extract was evaporated to dryness. The residues were dissolved in acetic anhydride, and chloroform was then added. Concentrated sulphuric acid was then added by the side of the test tube. A brown ring at the interphase of the two liquids and the appearance of violet colour in the supernatant layer indicated the presence of steroids.

\section{Test for tannins}

This was carried out according to the method described by Ciulci, (1994). Solutions of the extracts were made with distilled water and 3 drops of $5 \%$ ferric chloride solution was added. A green-black or blue-black colouration indicated the presence of tannins.

\section{BIOASSAY}

Preparation of extracts impregnated paper discs.

Two grams (2g) of each of the extracts were dissolved in $2 \mathrm{ml}$ of appropriate diluent (water for water extract and dimethyl sulpoxide (DMSO) for ethanolic extract), to yield $1.0 \mathrm{~g} / \mathrm{ml}(1,000,000 \mu \mathrm{g})$ solution. This was labeled as the stock solution. From the stock solution $0.1 \mathrm{ml}$ was transferred in to a bijou bottle containing $0.9 \mathrm{ml}$ diluent, to effect 10 times dilution which gave a concentration of $(100,000 \mu \mathrm{g} / \mathrm{ml})$. Subsequently $0.1 \mathrm{ml}$ was transferred in to another bottle containing $0.9 \mathrm{ml}$ diluent which gave a concentration of $10,000 \mu \mathrm{g} / \mathrm{ml}$ and this was further diluted to yield $1,000 \mu \mathrm{g} / \mathrm{ml}$, $100 \mu \mathrm{g} / \mathrm{ml}$ and $10.0 \mu \mathrm{g} / \mathrm{ml}$, on pro-rata basis. One hundred discs (100) discs, $6.0 \mathrm{~mm}$ diameter of Whatman No. 1 filter paper were impregnated with the extracts to arrive at concentrations 1000, 100 and $10 \mu \mathrm{g} /$ disc respectively. Greater disc potencies of 2,000, and 3,000 $\mathrm{gg} / \mathrm{disc}$ were also prepared and stored in refrigerator before use (Deeni and Hussein, 1991)

\section{Growth Media}

Plates of Mueller Hinton agar (Oxoid) were prepared according to the manufacturer's instructions. Excess moisture was removed by drying in agar dryer for 15 minutes.

\section{Preparation of Turbidity Standard}

One per cent $(1 \% \mathrm{v} / \mathrm{v})$ solution of sulphuric acid was prepared by adding $1 \mathrm{ml}$ of concentrated $\left(\mathrm{H}_{2} \mathrm{SO}_{4}\right)$ into $99 \mathrm{ml}$ of water. One per cent $(1 \% \mathrm{w} / \mathrm{v})$ solution of barium chloride was also prepared by dissolving $0.5 \mathrm{~g}$ of dehydrated barium chloride in $50 \mathrm{ml}$ distilled water. Barium chloride solution $(0.6 \mathrm{ml})$ was added to $99.4 \mathrm{ml}$ of sulphuric acid solution to yield $1.0 \% \mathrm{w} / \mathrm{v}$ barium sulphate suspension. The turbid solution formed was transferred into a test tube as the standard for comparison (Cheesebrough, 2000). 


\section{Standardization of inoculum}

Using inoculation loop, enough material from an overnight culture of test organisms that is $E$. coli, Salmonella and Staphylococcus aureus (isolated from meat) were transferred into a tube containing about $2.0 \mathrm{ml}$ normal saline, until the turbidity of the suspension matched the turbidity of the standard ( $1 \%$ barium sulphate) (Cheesebrough 2000).

Sensitivity testing of the isolates to the extracts Two loopfuls of the standard inoculum were evenly streaked on to the plates in duplicates. Discs of different concentrations as well as the control discs (impregnated with only diluent) were placed firmly on the surface of the medium (Mueller Hinton agar) by means of sterile syringe needle at about $40 \mathrm{~mm}$ apart. The plates were incubated at $37^{\circ} \mathrm{C}$ for 24 hours. Diameters of the zones of inhibitions were measured with ruler and the mean recorded to the nearest (mm).

\section{RESULTS}

Results of the physical characteristics and phytochemical analysis of the spice ingredients are as presented in Tables 1 and 2 below. In Table 1 , the extracts have different colours ranging from red, brown to dark brown, with some oily and some gummy in texture, while all have a spicy smell. In Table 2, all the extracts except water extract of West African black pepper contained alkaloids, flavonoids and reducing sugars. Saponins were detected in all the extracts except ethanolic extract of West African black pepper. Steroids were detected in water extracts of pepper, ethanolic and water extract of ginger, and water extract of cloves, while in the others no steroids was detected. Tannins were detected in pepper water extract, Ginger water extract, cloves ethanolic and water extract then West African black pepper water extract.

The results of the bioactivity of the extracts on the test organisms is as presented in Tables 3 and 4 , where the ethanolic extracts of cloves, ginger and WABP of the spices were active on Salmonella spp and also the ethanolic extracts of pepper and cloves were active on Staphylococcus aureus. The mixture of extracts from all the spices how ever was not active against the test organisms at the disc concentrations used.

Table 1: Some physical characteristics of the extracts from spices

\begin{tabular}{lcccc}
\hline Extract & Colour & Texture & Solubility & Smell \\
\hline Pepper ethanol & Red & Oily & DMSO & Spicy \\
Pepper water & Dark brown & Oily & Water & Spicy \\
Ginger ethanol & Brown & Gummy & DMSO & Spicy \\
Ginger water & Dark brown & Gummy & Water & Spicy \\
Cloves ethanol & Brown & Gummy & DMSO & Spicy \\
Cloves water & Dark brown & Gummy & Water & Spicy \\
WABP ethanol & Brown & Oily & DMSO & Spicy \\
\hline
\end{tabular}

Key: WABP $=$ West African black pepper

Table 2: Phytochemical composition of spices used in kilishi processing

\begin{tabular}{|c|c|c|c|c|c|c|}
\hline Extract & Alkaloids & Flavonoids & Saponins & Red. sugars & steroids & Tanins \\
\hline Pepper ethanol & + & + & + & + & - & - \\
\hline Pepper water & + & + & + & + & + & + \\
\hline Ginger ethanol & + & + & + & + & + & - \\
\hline Ginger water & + & + & + & + & + & + \\
\hline Cloves ethanol & + & + & + & + & - & + \\
\hline Cloves water & + & + & + & + & + & + \\
\hline WABP ethanol & + & + & - & + & - & - \\
\hline WABP water & - & + & + & + & - & + \\
\hline
\end{tabular}

Key: WABP $=$ West African black pepper, $+=$ detected, $-=$ not detected

Table 3: Bioactivity of spice extracts from spice, on Salmonella spp isolated from kilishi

\section{Extract}

\begin{tabular}{lccccc} 
& $\mathbf{1 0} \mathbf{\mu g}$ & $\mathbf{1 0 0} \mathbf{~ g}$ & $\mathbf{1 0 0 0} \mathbf{~ g}$ & $\mathbf{2 0 0 0} \mathbf{~ g}$ & $\mathbf{3 0 0 0} \mathbf{~ g}$ \\
\hline Pepper ethanol & 00 & 00 & 00 & 00 & 00 \\
Pepper water & 00 & 00 & 00 & 00 & 00 \\
Ginger ethanol & 00 & 08 & 19 & 26 & 30 \\
Ginger water & 00 & 00 & 00 & 00 & 00 \\
Cloves ethanol & 13 & 24 & 25 & 26 & 26 \\
Cloves water & 00 & 00 & 00 & 00 & 08 \\
WABP ethanol & 12 & 14 & 20 & 22 & 23 \\
WABP water & 00 & 00 & 00 & 00 & 00 \\
\hline
\end{tabular}

Key : WABP $=$ West African black pepper, $\mu \mathrm{g}=$ microgram 
Bajopas Volume 2 Number 1 June, 2009

Table 4: Bioactivity of extracts from spice, on Staph. aureus isolated from meat

\begin{tabular}{lccccc}
\hline Extract & \multicolumn{6}{c}{ Diameter of zone of inhibition $\mathbf{( m m )}$} & \\
& $\mathbf{1 0} \mathbf{m g}$ & $\mathbf{1 0 0} \mathbf{~ g}$ & $\mathbf{1 0 0 0} \mathbf{~ g}$ & $\mathbf{2 0 0 0} \mathbf{~ g g}$ & $\mathbf{3 0 0 0} \mathbf{\mu g}$ \\
\hline Pepper ethanol & 12 & 11 & 16 & 22 & 34 \\
Pepper water & 00 & 00 & 00 & 00 & 00 \\
Ginger ethanol & 00 & 00 & 00 & 00 & 00 \\
Ginger water & 00 & 00 & 00 & 00 & 00 \\
Cloves ethanol & 12 & 13 & 13 & 17 & 22 \\
Cloves water & 00 & 00 & 00 & 00 & 00 \\
WABP ethanol & 00 & 00 & 00 & 00 & 00 \\
WABP water & 00 & 00 & 00 & 00 & 00 \\
\hline
\end{tabular}

Key: $\mathrm{WABP}=$ West African black pepper,$\mu \mathrm{g}=$ microgram

\section{DISCUSSION}

According to Pruthi (1980), properties of spices include bactericidal, bacteriostatic, fungistatic, antihelminstic, medicinal and flavouring. From the result of this study, it is clear that not all the spices extracts were active against the test organisms. Even those that were active were the ethanolic extracts the water extracts were not active. Considering the fact that the spices are used in combination during the production of the traditional meat product (kilishi) and the mixture of all the extracts of the spices was not active against the test organisms at the disc concentrations used, the effect of the spices on the

\section{Conclusion and Recommendations}

It could be concluded that the ethanolic extract of the spices have potential for use in the development of antimicrobial drugs. The spices are active against the test organisms individually but in combination the

\section{REFERENCES}

Brain, K. R. and Turner, T. D. (1975). The practical evaluation of phytopharmaceuticals. Wright Scientechica, Bristol: 57-58.

Cheesebrough, M. (2000). District Laboratory practice in Tropical Countries. Part 2. Cambridge University Press. Pp76-100.

Ciulci, I. (1994). Methodology for the analysis of vegetable drugs. Chemical industries branch, Division of industrial operations. UNIDO, Romania: Pp 24, 26 and 67.

Deeni Y. Y. and Hussein, H. S. N. (1991): Antibiotic sensitivity testing. Journal of Ethnopharmacognosy. pp 91-96.

Fatope A. O., Ibrahim H. and Takeda Y. (1993): Screening of higher plant reputed as pesticides using the brine shrimp lethality bioassay. International Journal of pharmacognosy. 31: 250-256.

Food and Agriculture Organization of the United Nations FAO (1979): Manuals of food quality contro/4. Microbiological analysis. D1-D37.

Frazier, W. C. and Westthroff, W. C. (2006). Food microbiology $3^{\text {rd }}$ Edition, McGraw Hill microbial loads of the meat product would not be remarkable. This also signifies that, individually the extracts of the spices are more active against the test organisms than when they were combined. According to Frazier and Westhoff (2006), spices and condiments do not have any marked bacteriostatic effect in the concentrations normally used but may help other agents in preventing the growth of microorganisms. They also showed that unless the spices are treated to reduce their microbial content, they may add high numbers and undesirable kinds of microorganisms as observed from this study.

activity is lost. It could therefore be recommended that spices should be treated to reduce their microbial loads, and potable water should always be used in their preparation.

Publishing Company Limited New York. Pp163-165, 223-236, 419-543.

International Standards Organizatio, (ISO) (1972). Spices and condiments. Women culture Finchized Draft Proposal. Tc-34/Sc-7, 150 Budapest.

Pruthi, J. S. (1980). Spices and condiments: Chemistry, microbiology, biotechnology. Adv. Food Res. Supple 16-17. Academic Press, New York.

Shamsudden U. (2009): Microbiological hazard analyses and Critical control points of some meat products processed in Kano metropolis. $\mathrm{Ph}$. D. Thesis, Department of Biological sciences Bayero University Kano.

Sofowora, A. A. (1993). Medicinal Plants and Traditional Medicines in Africa. Spectrum books Ltd., Ibadan Nigeria: 2. Pp81-85.

Vilar, I., Garcia M. C., Fontan, B., Tornadijo, M. E and Carballo J. (2000): A survey of the microbiological changes during the manufacture of dry cured lacon, a Spanish traditional meat product. Journal of Applied Microbiology 89, 1018-1026 